\title{
Evaluation of Archaeological Material from the Little Church of La Villita Property, San Antonio, Texas
}

Cynthia L. Tennis

Center for Archaeological Research

Follow this and additional works at: https://scholarworks.sfasu.edu/ita

Part of the American Material Culture Commons, Archaeological Anthropology Commons, Environmental Studies Commons, Other American Studies Commons, Other Arts and Humanities Commons, Other History of Art, Architecture, and Archaeology Commons, and the United States History Commons

Tell us how this article helped you.

This Article is brought to you for free and open access by the Center for Regional Heritage Research at SFA ScholarWorks. It has been accepted for inclusion in Index of Texas Archaeology: Open Access Gray Literature from the Lone Star State by an authorized editor of SFA ScholarWorks. For more information, please contact cdsscholarworks@sfasu.edu. 
Evaluation of Archaeological Material from the Little Church of La Villita Property, San Antonio, Texas

\section{Creative Commons License}

(c) (1) (8)

This work is licensed under a Creative Commons Attribution-NonCommercial 4.0 International License 


\title{
EVALUATION OF ARCHAEOLOGICAL MATERIAL FROM THE LITTLE CHURCH OF LA VILLITA PROPERTY, SAN ANTONIO, TEXAS
}

\author{
Cynthia L. Tennis \\ Robert J. Hard, Jack D. Eaton, and Anne A. Fox, \\ Principal Investigators
}

Texas Antiquities Committee Permit No. 1279

Center for Archaeological Research The University of Texas at San Antonio Archaeological Survey Report, No. 228

1994 

The following information is provided in accordance with General Rules of Practice and Procedure Chapter 41.11 (Investigation Reports), Texas Antiquities Committee:

1. Type of investigation: Site inspection, collection, and analysis of human burial;

2. Project name: Little Church of La Villita (41BX917);

3. County: Bexar County, Texas;

4. Principal investigators: Jack D. Eaton, principal investigator, 1993; Robert J. Hard, principal investigator, 1994; Anne A. Fox, coprincipal investigator;

5. Name and location of sponsoring agency: San Antonio Parks and Recreation Department, San Antonio, Texas;

6. Texas Antiquities Committee Permit No. 1279;

7. Published by the Center for Archaeological Research, The University of Texas at San Antonio, San Antonio, Texas 78249-0658, 1994.

A list of publications offered by the Center for Archaeological Research can be obtained by sending $\$ 1.00$ to the Center for Archaeological Research, The University of Texas at San Antonio, San Antonio, Texas 78249-0658. 

ABSTRACT

\begin{abstract}
On June 25th, 1993, Dale Bransford of the San Antonio Parks and Recreation Department brought several bone fragments to the Center for Archaeological Research (CAR) of the University of Texas at San Antonio (UTSA). These bones had been discovered by workmen installing a French drain along the east side of the Little Church of La Villita in downtown San Antonio. Inspection identified the bones as human, so CAR staff members visited the site to investigate and collect other remains. No excavation was attempted.
\end{abstract}

Subsequent skeletal analysis revealed the presence of at least two individuals in the collection. Because of the absence of diagnostic artifacts, a sample of bone was sent for accelerator dating. The resulting date of $380 \pm$ 60 B.P. (Beta-67731 AMS-9901) suggests that these remains are those of at least two late prehistoric or protohistoric occupants of south central Texas. The $\delta^{13} \mathrm{C}$ value of the bone indicates a dietary regime which emphasized C4based food sources, in this case probably bison. 
TABLE OF CONTENTS

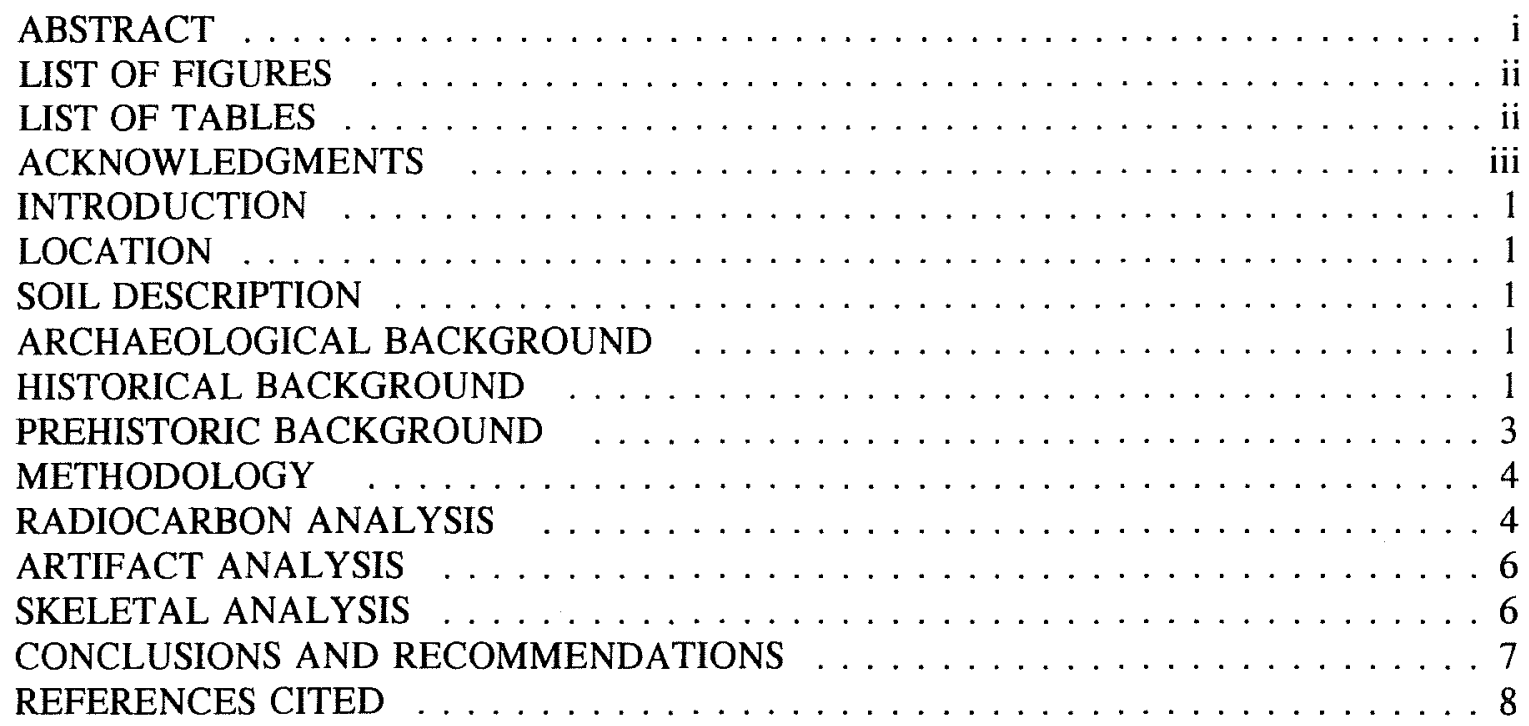

\section{LIST OF FIGURES}

1. Location of the Little Church of La Villita $(41 \mathrm{BX} 917) \ldots \ldots \ldots \ldots$

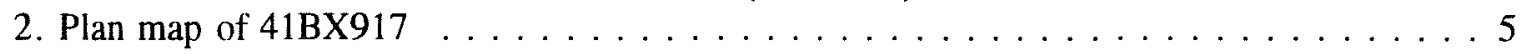

\section{LIST OF TABLES}

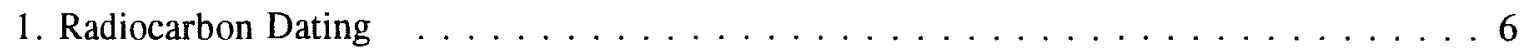




\section{ACKNOWLEDGMENTS}

I wish to acknowledge the conscientious efforts displayed by Dale Bransford of the San Antonio Parks and Recreation Department and Killis Almond, project architect, in bringing this burial area to our attention. Dr. Barbara Winkler's assistance with the skeletal analysis is greatly appreciated.

During the fieldwork phase, the principal investigator was Jack D. Eaton, acting director of the Center for Archaeological Research (CAR). Robert J. Hard, director of CAR, assumed this responsibility during the analysis and report-preparation stages; I would like to thank him for his assistance in obtaining radiocarbon dates for the remains.
Site inspection and laboratory processing were conducted by Anne Fox, Waynne Cox, and José Zapata, CAR staff members. Marcie Renner, technical editor, prepared the manuscript for publication. 



\section{INTRODUCTION}

In June 1993, representatives of the San Antonio Parks and Recreation Department notified the Center for Archaeological Research (CAR) of the University of Texas at San Antonio (UTSA) of the presence of possible human remains which had been uncovered during a minor handtrenching project at the Little Church of $\mathrm{La}$ Villita in downtown San Antonio. Inspection at the site revealed fragments of human bone distributed throughout the trench backdirt. No indication of additional portions of the burial or burial pit remained in the trench, although remnants of a foundation evidently predating the church construction were noted. No excavation was attempted. The skeletal remains, along with several lithic artifacts, were collected, photographs were taken, and a plan map was drawn of the foundation exposed in the trench. Skeletal remains were transported to the laboratory at CAR for processing and analysis.

The Little Church of La Villita is part of the La Villita Historic District. The district is owned by the city of San Antonio and its operation and maintenance are under the direction of the San Antonio Parks and Recreation Department. Our investigations revealed that although the $\mathrm{La}$ Villita Historic District was placed on the National Register of Historic Places in 1972, it had not previously been designated an archaeological site. Therefore, a state trinomial identification number, 41BX917, was obtained for NCB 114, Lot 12, the location of the Little Church of La Villita. The following skeletal analysis and documentation was conducted under Texas Antiquities Committee Permit 1279.

\section{LOCATION}

The Little Church of La Villita, in downtown San Antonio, fronts on Villita Street, one-half block west of Alamo Street (Figure 1). The church is part of the La Villita Historic District, placed on the National Register of Historic Places in 1972. This historic district is located on the southern terrace of the San Antonio River approximately $650 \mathrm{ft}$ above mean sea level (Fox et al. 1988).

\section{SOIL DESCRIPTION}

Like most areas in downtown San Antonio, the soil in La Villita and under the Little Church of La Villita in particular is a compact, dark brown clay loam, identified by Taylor et al. (1966) as Houston Black Clay.

\section{ARCHAEOLOGICAL BACKGROUND}

The earliest archaeological work in the general area of La Villita was done in the late 1930s and early 1940s as part of the Works Project Administration (WPA) program. This work was confined to restoration of several buildings in the blocks south and west of the Little Church and to the Cós House on the north side of Villita Street as well as construction of the Arneson River Theatre on the river itself.

Other archaeological projects in the Historic District include those done by Fox et al. (1978), Fox et al. (1988), Ivey (1978), Katz (1978), Labadie (1986), and Schuetz (1970), all dealing with historic period structures and occupations. No archaeological work has been done at the Little Church proper and no prehistoric archaeological investigations have taken place in the historic district.

\section{HISTORICAL BACKGROUND}

La Villita, The Little Village, probably began as a small settlement housing the families of soldiers stationed in the nearby presidio San Antonio de Bexar. The little town grew, thanks in part to its location at the only ford along the San Antonio River that connected the main part of Spanish San Antonio with the missions to the 


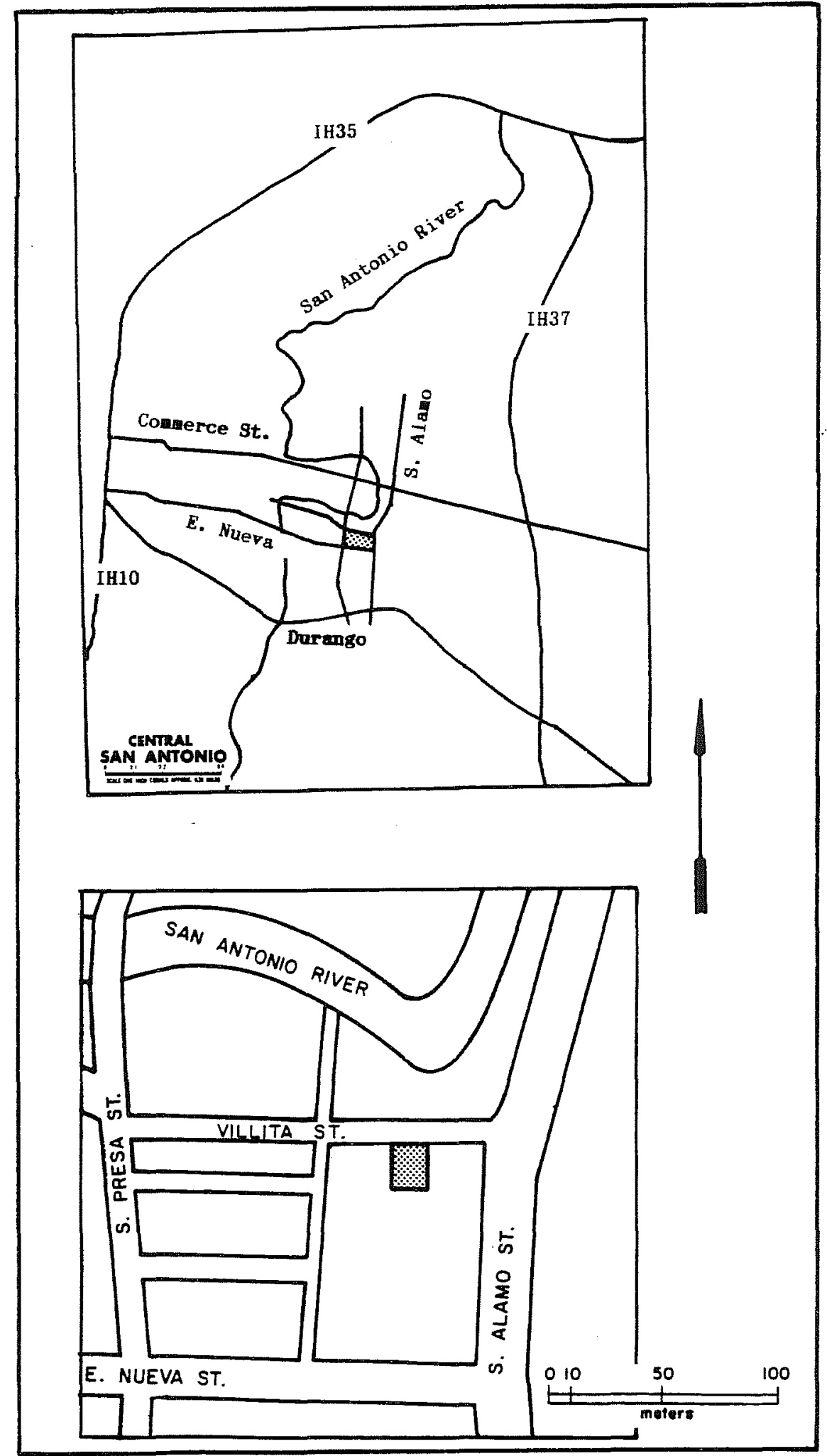

Figure 1. Location of the Little Church of La Villita (4IBX917). 
south. Present day Villita Street was called the "Street of the Crossing" and today's South Alamo was "the road to the missions" (Ramsdale 1959:110-111). The high bluff on the La Villita side of the river became a favored site for more affluent Spanish residences after the flood of 1819 destroyed much of the city proper.

Events involving both sides in the Texas Revolution against Mexico took place in La Villita. In 1835 when the Texan Army defeated the troops of General Cós in the Battle of Bexar, Cós signed the capitulation in a house which still stands in La Villita. The next year, La Villita served as a strategic location for Santa Anna's attack during the Battle of the Alamo.

As Texas became part of the Union, a new influx of settlers came to Texas. Many settled along the river in La Villita, adding distinctive French- and German-style cottages to the Mexican structures already there. The area remained a respectable middle class neighborhood until the end of World War I and the Great Depression (Ramsdale 1959:110-111).

In 1939, through the direct influence of Mayor Maury Maverick, the city assumed ownership of La Villita and, with the help of funds obtained from the WPA, restored the old Spanish village as "a symbol of the city's past" (City Council Proceedings [CCP] August 3, 1939 Vol. Q:168). La Villita was placed on the National Register of Historic Places in 1972, and is maintained by the San Antonio Parks and Recreation Department.

\section{LOT HISTORY}

After secularization of the Spanish mission in 1793, the farmlands of the deserted mission San Antonio de Valero (the Alamo) as well as the small settlement outside the mission (La Villita) were divided and deeded to citizens requesting land. The plot of land under investigation here was part of a tract of land granted-sometime before 1811-to Clemente Delgado, the younger son of the widow Meleano Delgado, one of the original Canary Islanders settlers (Bexar County
Archives [BCA], Land Grant and Sales File No. 40, Heritage Plaza Building, San Antonio). The property of Clemente Delgado, along with that of many other citizens, was confiscated during the civil unrest of 1812 and 1813 , only to be returned in attempts to repopulate the villa (Padilla 1919:64).

Upon Delgado's death in 1836 the property passed to his eight children (BCA, Wills and Estates, No. 32) and remained intact for 30 years. In 1865 the land was divided and two lots, including the one under investigation, were sold to Juan Cantu (Bexar County Deed Records [BCDR], Office of the City Clerk, Heritage Plaza Building, Volume T2:13). The property was then sold to S. W. McAllister in 1866, who sold it to Phillip Johns that same year (BCDR U1:199). Johns sold the property to William D. Smithin in 1872 ; the latter sold the property to the Catholic church for the construction of the structure now known as "The Little Church of La Villita" in 1876 (Ramsdell 1959:108). The church passed the structure and the adjacent lot to the African-American parish, which established St. Philip's seminary on the site in 1898. The property later passed to the Carmelite Sisters, then was conveyed to the city of San Antonio by Archbishop Robert E. Lucy in 1957 (BCDR 2278:559).

\section{PREHISTORIC BACKGROUND}

Much archaeological information about the prehistory of southern Texas has been gathered from in and around Bexar County. However, early Colonial period and modern development along the San Antonio River has limited our knowledge of prehistoric occupations along this important waterway. With the exception of the St. Mary's Hall site (41BX229)-a possible Paleoindian occupation site excavated by a UTSA field school in 1977 (Hester 1978)-and the Middle Archaic cemetery site (41BX1) at Olmos Dam (Lukowski 1988), the prehistoric past of downtown San Antonio is unknown. 
The end of the Late Prehistoric occupation, the Toyah phase, is the most relevant to the $\mathrm{La}$ Villita skeletal remains. Late Prehistoric site data indicate the continuation of established huntergatherer subsistence patterns with a heavy reliance on a wide variety of game including deer, pronghorn antelope, and bison. The availability of fresh water was a primary factor in site location, as most sites are located within $50 \mathrm{~m}$ of a reliable water source (Black 1989).

Less than 100 years after the end of the Late Prehistoric period, eyewitness accounts from two Spanish travelers relate the presence of a Native American settlement on the San Antonio River at a point somewhere within the present city limits of San Antonio (Campbell 1975). The inhabitants, known as Payaya, were occupying an encampment described as a cluster of shelters in a wooded area near the river. In these accounts a local stream was referred to as El Arroyo de los Payayas and a pass through the hills northwest of San Antonio is called the Puerto de los Payayas. The Payaya are prominent among the inhabitants of the Mission San Antonio de Valero from its founding in $\mathbf{1 7 1 8}$ until 1776.

\section{METHODOLOGY}

As noted earlier, the hand-dug trench along the west wall of the Little Church of La Villita was completed before CAR staff members arrived at the site. Since this trench was within the foundation trench previously excavated during the construction of the church and the area disturbed by the earlier structure that had occupied the site, the artifacts collected appear to have been redeposited with the backfill. There is no evidence that the original stratigraphy remained intact. The trench was inspected, photographs were taken, and a plan map was drawn. The trench was three feet in width and extended to a depth of 28 to 30 inches below the surface. The remnants of three one-foot-thick limestone walls were visible in the bottom of the trench (Figure 2). Bone and chert artifacts were collected from the trench back dirt and returned to the CAR lab for processing and analysis.

The chert artifacts and bone in the trench backdirt suggest the burial was Spanish-colonial period or earlier in origin. A prehistoric date is most likely because during the later part of the Spanish-colonial period, the cemetery was located at San Fernando Cathedral; thus a burial from this period at La Villita is unlikely. Furthermore, the Little Church of La Villita is a nineteenth-century structure, so the burial is thought not to be associated with it.

\section{RADIOCARBON ANALYSIS}

In order to evaluate the age of the skeletal remains, a $21 \mathrm{~g}$ sample of bone from one individual was submitted to Beta Analytic Inc. for collagen radiocarbon dating using the Accelerator Mass Spectrometry (AMS) technique. The process produced a ${ }^{13} \mathrm{C}$ adjusted, two-sigma-calibrated date of A.D. 1420 (1476) 1650 , suggesting the remains date to the period immediately prior to Spanish settlement. Table 1 summarizes the analysis. The calibration was based on Stuiver and Becker's (1987) 10-year calibration curve.

The high $\delta^{13} \mathrm{C}$ value of $-12.1 \%$ indicates a diet with substantial levels of $\mathrm{C} 4$ resources. The most likely sources of $\mathrm{C} 4$ dietary elements for this region would either be bison which had been feeding on C4 grasses, or maize. Maize would not have played a role in the diet at the time period indicated by the radiocarbon date. During the Toyah phase, bison are thought to have been an important resource, which may indeed be reflected by the high $\mathrm{C} 4$ signature. Clearly the isotopic signature of human bone from this time period may be a significant avenue for further research. 


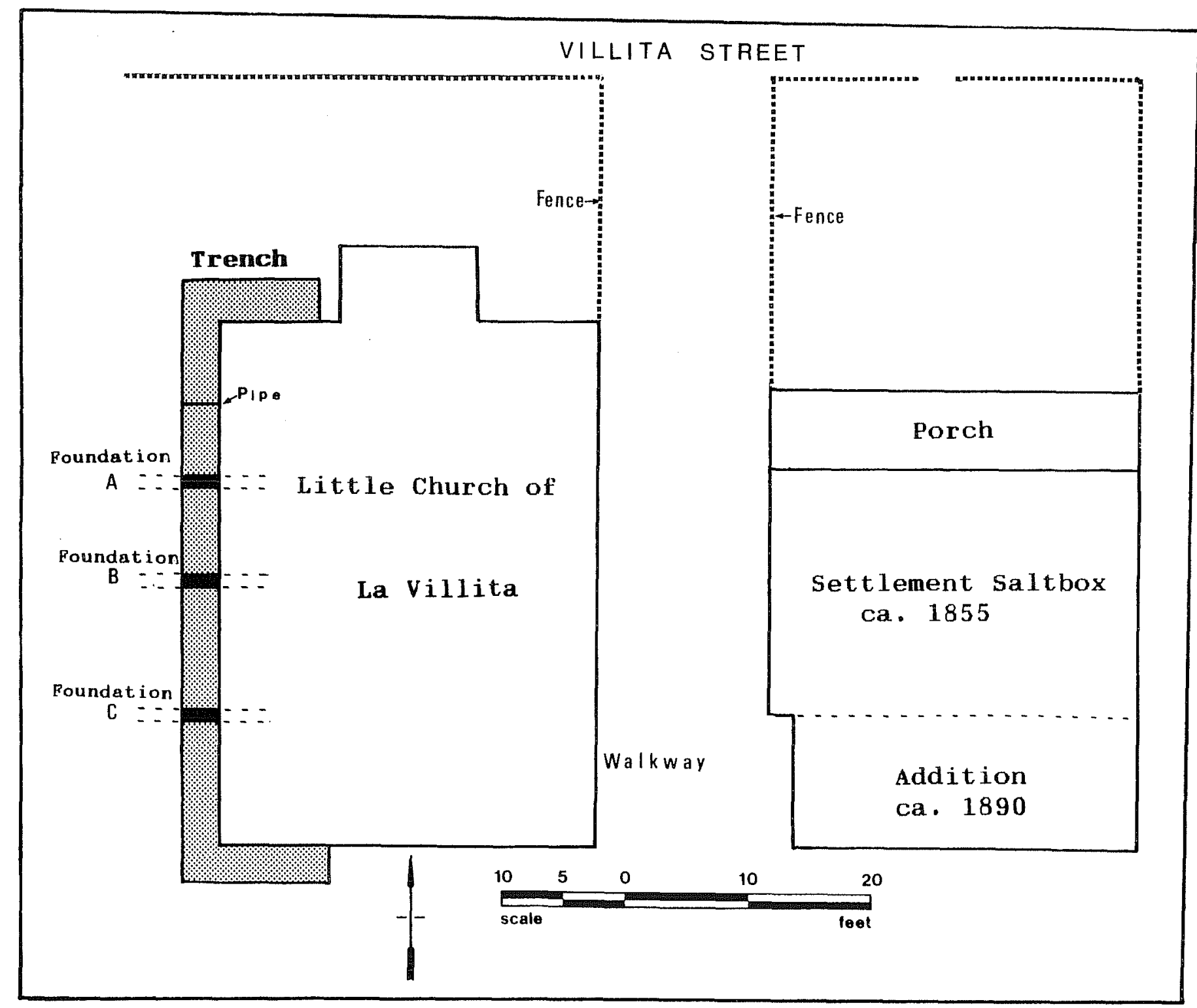

Figure 2. Plan map of 41 BX917. 
Table 1. Radiocarbon Dating

\begin{tabular}{|c|c|c|c|c|c||}
\hline \hline Sample No. & Uncalibrated & $\delta^{13} \mathrm{C}$ & ${ }^{13} \mathrm{C}$ Adjusted & $\begin{array}{c}\text { 1 Sigma } \\
\text { Tree-ring } \\
\text { Calibrated }\end{array}$ & $\begin{array}{c}\text { 2 Sigmas } \\
\text { Tree-ring } \\
\text { Calibrated }\end{array}$ \\
\hline $\begin{array}{c}\text { Beta } 67731 \\
\text { AMS } 9901\end{array}$ & B.P. $170 \pm 60$ & $-12.1 \% 0$ & B.P. $380 \pm 60$ & $\begin{array}{c}\text { A.D. } 1438 \\
(1476) 1630\end{array}$ & $\begin{array}{c}\text { A.D. } 1420 \\
(1476) 1650\end{array}$ \\
\hline \hline
\end{tabular}

\section{ARTIFACT ANALYSIS}

Five chert flakes-three primary and two tertiary-were recovered from the back dirt. These flakes range in color from gray to tan and all display prominent striking platforms and bulbs of percussion, but do not show evidence of retouch or use wear.

\section{SKELETAL ANALYSIS}

The following analysis of the skeletal remains from 41BX917 was done with the assistance of Dr. Barbara Winkler, physical anthropologist at UTSA, and comparisons with illustrations found in White and Folkens (1991). The following identifiable human elements were present:

Vertebrae

1 axis vertebra

\section{Long Bones}

1 left ulna - distal and proximal

1 left radius - distal and proximal

1 left tibia - distal

Shoulder Girdle

1 left clavicle
Hands

1 right lunate

1 right capitate

1 left capitate

1 left trapezium

1 left humate

1 right scaphoid

4 right metacarpals - 2, 3, 4, 5

4 left metacarpals - 2, 3, 4, 5

4 proximal phalanges

4 intermediate phalanges

Feet

2 right tali

2 right first metatarsals

2 right fifth metatarsals

6 proximal foot phalanges

1 intermediate foot phalange

Dentition

1 upper left M3

1 upper left M1

1 upper right $\mathrm{P} 3$

1 upper right $\mathrm{P} 4$

1 lower right $\mathrm{I1}$

1 lower right $\mathrm{I} 2$

The fragmented and deteriorated nature of the recovered skeletal remains made further identification impossible. However, the fact that the collection contains bones from two right feet indicates the presence of at least two individuals. 


\section{CONCLUSIONS AND RECOMMENDATIONS}

Considerable similarities are seen between the dimensions of the existing house to the east of the church and the limestone foundation remnants exposed in the bottom of the trench, as illustrated in Figure 2. Foundation remnants labeled " $\mathrm{A}$ " and " $\mathrm{C}$ " closely correspond to the front and back walls of the ca. 1855 portion of the adjacent structure, while remnant "B" could represent an interior wall. The 14-ft walkway between the church and the house and the fences in front of the two structures are all recent modifications to the properties. No record could be found of the existence of a house on the lot under investigation, but records do indicate that the existing house to the east was constructed in 1855 (San Antonio Conservation Society, Vertical Files, Wolfe House, San Antonio, Texas). This house was constructed before the original land grant to the Delgado family was broken up; that there were two similar structures which were part of a Delgado family compound is possible.

In all likelihood the fragmented and disturbed nature of the human burials at the Little Church of La Villita is not solely the result of the current trenching activities. The construction of the ca. 1855 structure and the later church undoubtedly intruded into the original grave area. Nevertheless, the fact that partial remains of more than one protohistoric burial were recovered is important. When this information is combined with that from a 1942 newspaper report (San Antonio Evening News, 18 November 1942:4) of a "100 year old" skeleton found in the courtyard of the Little Church of La Villita, the significance of the area increases.
Archaeological evidence from south Texas indicates the preference for riverside settlement locations and journal entries from Spanish explorers describe a large Payaya encampment along the San Antonio River within the present city boundaries. The presence of at least three burials, one of which dates to A.D. 1420-1650, and stone artifacts on a terrace overlooking the San Antonio River strongly suggests that a protohistoric site exists under the Little Church of La Villita.

The area around and below the Little Church of La Villita contains deposits of both historic and prehistoric significance. For this reason, we strongly recommend that land modification in this area be limited, and when necessary, closely monitored by qualified archaeologists. 


\section{REFERENCES CITED}

Black, S. L.

1989 South Texas Plains. In From the Gulf to the Rio Grande: Human Adaptation in Central, South, and Lower Pecos Texas, by T.R. Hester, S. L. Black, D. G. Steele, B. W. Olive, A. A. Fox, K. J. Reinhard, and L. C. Bement, pp.39-62. Arkansas Archeological Survey Research Series No.33, Fayetteville.

Campbell, T. N.

1975 The Payaya Indians of Southern Texas. Special Publication No 1. Southern Texas Archaeological Association, San Antonio.

Fox, A. A., B. A. Nightengale, and I. W. Cox 1988 Archaeological Investigations at the Navarro Street Parking Garage, San Antonio, Texas. Archaeological Survey Report, No. 174 Center for Archaeological Research, The University of Texas at San Antonio.

Fox, D. E., F. Valdez, Jr., and L. O. Bobbitt

1978 The Delores Aldrete House Property, San Antonio, Texas. Archaeological Survey Report 58. Center for Archaeological Research, The University of Texas at San Antonio.

Hester, T. R.

1978 Early Human Occupations in South Central and Southwestern Texas: Preliminary Papers on the Baker Cave and St. Mary's Hall Sites. Center for Archaeological Research, The University of Texas at San Antonio.
Ivey, J. E.

1978 Archaeological Investigations at the Gresser House (41BX369, San Antonio, Texas. Archaeological Survey Report, No. 60. Center for Archaeological Research, The University of Texas at San Antonio.

Katz, P. R.

1978 Archaeological and Historical Investigations in the Arciniega Street Area, Downtown San Antonio, Texas. Archaeological Survey Report, No. 61. Center for Archaeological Research, The University of Texas at San Antonio, Texas.

Labadie, J. H.

1986 La Villita Earthworks (41BX677): San Antonio, Texas. Archaeological Survey Report 159. Center for Archaeological Research, The University of Texas at San Antonio.

Lukowski, P. D.

1988 Archaeological Investigations at 4lBX1, Bexar County, Texas. Archaeological Survey Report, No. 135. Center for Archaeological Research, The University of Texas at San Antonio.

Padilla, J. A.

1919 Texas in 1820. Translated by M. A. Hatcher. Southwestern Historical Quarterly 23:47-68.

Ramsdell C.

1959 San Antonio: A Historical and Pictorial Guide. Revised edition by C. Perry 1976, University of Texas Press, Austin. 
San Antonio Evening News

194218 November.

Schuetz, M. K.

1970 The Cuarteles of San Antonio de Bexar. Unpublished manuscript on file, Center for Archaeological Research, The University of Texas at San Antonio.

Stuiver, M., and P. J. Reimer

1987 CALIB Rev 2.1. Quaternary Isotope Lab. University of Washington, Seattle.

Taylor, F. B., R. B. Hailey, and D. L. Richmond

1966 Soil Survey, Bexar County, Texas. U.S. Department of Agriculture, Soil Conservation Service in cooperation with Texas Agricultural Experiment Station, Series 1962(12).

White, T. D., and P. A. Folkens

1991 Human Osteology. Academic Press, Harcourt Brace Jovanovich, New York. 


